\title{
Uji Antioksidan Etosom Ekstrak Daun Jeruk Purut (Citrus hystrix D.C.) sebagai Anti Penuaan Kulit dengan Metode DPPH
}

\author{
Muhammad Okta Dody Muzuka*, Adeltrudis Adelsa Danimayostu, Siti Jazimah Iswarin \\ Jurusan Farmasi, Fakultas Kedokteran, Universitas Brawijaya, Malang, Indonesia
}

\section{INFO ARTIKEL \\ Sejarah artikel: \\ Penerimaan naskah: 27 \\ April 2017 \\ Penerimaan naskah \\ revisi: 6 April 2018 \\ Disetujui untuk \\ dipublikasikan: 26 Juni \\ 2018}

\section{Kata kunci :}

antioksidan,

hystric

Citrus

penuaan, $\alpha$-diphenyl- $\beta$ -

picrylhydrazyl (DPPH).
A B S T R A K

Proses utama yang berperan dalam menyebabkan penuaan kulit dapat dibagi menjadi dua, yaitu intrinsik dan ekstrinsik. Penuaan intrinsik disebabkan oleh faktor genetik dan pertambahan usia. Penuaan ekstrinsik disebabkan oleh faktor-faktor lingkungan seperti paparan sinar matahari, polusi udara, rokok, dan kekurangan gizi. Ekstrak daun jeruk purut mengandung senyawa alkaloid, flavonoid, terpenoid, dan fenol yang memiliki aktivitas antioksidan. Efek antioksidan yang paling potensial dimiliki ekstrak daun jeruk purut adalah flavonoid, alkaloid dan fenol. Etosom adalah sistem penghantaran obat yang terdiri dari fosfolipid, etanol dan air sebagai pelarut bebas. Adanya etanol dapat menurunkan transisi suhu dari lipid stratum korneum dan meningkatkan fluiditas. Metode yang digunakan adalah $\alpha$-diphenyl- $\beta$ picrylhydrazyl (DPPH). Rendemen ekstrak diperoleh sebesar 9,85\% dengan pelarut etanol 96\%. Hasil uji etosom daun jeruk purut pada organoleptik yaitu zat cair, berbau khas aromatis dan warna hijau kekuningan. Hasil uji skrining fitokimia mengandung senyawa flavonoid, fenol, terpenoid dan alkaloid. Hasil uji pH formula 1 sebesar 6,170 $\pm 0,077$; formula 2 sebesar 6,140 $\pm 0,076$ dan formula 3 sebesar $6,129 \pm 0,076$. Hasil uji ukuran vesikel formula 1 sebesar $17,086 \pm 28,491$; formula 2 sebesar 52,872 \pm 42,553 dan formula 3 sebesar $27,489 \pm 38,634$. Hasil uji morfologi yaitu spheris. Hasil uji nilai antioksidan $\mathrm{IC}_{50}$ ekstrak daun jeruk purut sebesar 25,907 $\pm 0,187$; etosom ekstrak daun jeruk purut formula 1 sebesar $28,814 \pm 0,431$; formula 2 sebesar 32,299 $\pm 1,893$ dan formula 3 sebesar 30,234 \pm 0,531 yang menunjukkan ketiga formula memiliki aktivitas antioksidan yang sangat kuat. Hasil uji stabilitas dilakukan hari ke-0, ke- 15 , dan ke-30 pada suhu $25^{\circ} \mathrm{C} \pm 2{ }^{\circ} \mathrm{C}$ dengan relative humidity $60 \% \pm$ $5 \%$ sediaan stabil selama penyimpanan . Uji pH etosom memenuhi spesifikasi $\mathrm{pH}$ kulit yaitu sebesar 4,56,6 .

\section{Antioxidant Test of Ethosome Kaffir Lime Leaves (Citrus hystrix D.C.) Extract as Skin Anti-Aging with DPPH Method}

\section{Keywords:}

antiaging, antioxidant, Citrus hystric D. C., ethosome, $\alpha$-diphenyl$\beta$-picrylhydrazyl .

\begin{abstract}
A B S T R A C T
The main processes causing aging skin can be divided into two types, which are intrinsic and extrinsic. Intrinsic aging is caused by genetic factors and increasing age. Extrinsic aging is caused by environmental factors such as sunlight exposure, air pollution, smoking, and malnutrition. Kaffir lime leaf's extract contains alkaloids, flavonoids, terpenoids and phenols that have antioxidant activity. Ethosome is a drug delivery system primarily composed of phospholipids, ethanol, and water as a solvent. The presence of ethanol can decrease temperature transition of stratum corneum lipid and increase fluidity. Method used to determine antioxidant activity as antiaging was $\alpha$-diphenyl- $\beta$-picrylhydrazyl (DPPH). The ethosome formula was differentiated with three different concentrations of soya lecithin phospholipid with $1,5 \%$; $2,5 \%$ and $3 \%$. The kaffir lime leaves ethosome was tested with an organoleptic test, phytochemical screening, pH test, vesicles measurement, morphology test, antioxidant value, and stability test. The extract's yield was obtained $9.85 \%$ with ethanol $96 \%$ as a solvent and contained phenol, terpenoids, alkaloids and flavonoids on phytochemical screening. The stability test was conducted on day 0 , day 15 th, and day 30 th at $25 \mathrm{oC} \pm 2 \mathrm{oC}$ and relative humidity $60 \% \pm 5 \%$. The $\mathrm{pH}$ test of the ethosome complied the specifications of skin's $\mathrm{pH}$. The vesicles' size of each formula did not comply the specification goal of dermis. Antioxidants test showed that kaffir lime leaves ethosome had a very powerful antioxidant. It could be concluded that kaffir lime leaves extract was a potentially powerful antioxidants.
\end{abstract}




\section{Pendahuluan}

Kulit manusia seiring dengan pertambahan usia akan mengalami penuaan. Proses utama yang berperan menyebabkan penuaan kulit secara intrinsik dan ekstrinsik. Kulit yang mengalami penuaan ditandai dengan adanya keriput dan hipopigmentasi. ${ }^{1}$ Etosom adalah sistem penghantaran obat terutama terdiri dari fosfolipid, etanol dan air sebagai pelarut bebas. Adanya etanol mengakibatkan penurunan transisi suhu dari lipid stratum korneum dan meningkatkan fluiditas. Etanol akan berinteraksi dengan kutub polar pada kulit sehingga meningkatkan permeabilitas membran. ${ }^{2}$ Digunakan daun jeruk purut karena memiliki aktivitas antioksidan yang mengandung senyawa alkaloid, flavonoid, terpenoid dan saponin. ${ }^{3}$ Aktivitas antioksidan pada daun jeruk purut adalah $1 \mathrm{mg} / \mathrm{ml} .{ }^{4}$ Metode penentuan antioksidan yang dapat digunakan pada antipenuaan adalah $\alpha$-diphenyl- $\beta$-picrylhydrazyl (DPPH). Metode DPPH merupakan metode yang cepat, akurat, sederhana, murah, digunakan untuk mengukur kemampuan senyawa yang bertindak sebagai penangkap radikal bebas. Untuk mengetahui aktivitas antioksidan etosom ekstrak daun jeruk purut yang optimum menggunakan metode DPPH. ${ }^{5}$

\section{Metode}

\section{Pembuatan Ekstrak Etanol Daun Jeruk Purut (Citrus} hystrix D.C.)

Daun Jeruk Purut bersih dijemur di bawah sinar matahari selama 2 hari, dalam kondisi tertutup rapat, kemudian dipotong kecil-kecil dan dibuat serbuk. Serbuk ditimbang sebanyak 500 gram dan dimasukkan ke dalam toples dan ditambahkan etanol $96 \%$ sebanyak 2,5 liter. Serbuk dibiarkan selama dua hari. Kemudian ekstrak disaring dengan kain flanel dan kertas saring whatmann. Residu dilakukan maserasi kembali dengan etanol $96 \%$. Hasil ekstrak kemudian diuapkan menggunakan rotary evaporator selama 35 menit, suhu $60^{\circ} \mathrm{C}$, dan kecepatan 80 rpm untuk menguapkan etanol. Dioven hingga didapatkan ekstrak kental.

\section{Pembuatan Etosom}

Etosom dibuat dengan metode dingin. Lesitin, ekstrak, dan kolesterol dilarutkan dalam etanol $85 \%$ pada suhu ruang dalam wadah tertutup dengan pengadukan yang kuat menggunakan overhead stirrer dengan kecepatan 506 rpm. Propilenglikol ditambahkan selama pengadukan pada suhu ruang. Akuades ditambahkan ke campuran (lesitin, ekstrak, kolesterol, etanol 85\%, Propilen glikol) kemudian diaduk selama 20 menit dengan kecepatan $20.000 \mathrm{rpm}$ hingga homogen dalam wadah tertutup. Ukuran vesikel etosom akan menurun menggunakan metode sonikasi selama 45 menit. $^{6}$

\section{Skrining Fitokimia}

- Fenol

Menggunakan Ferric Chloride Test yaitu ekstrak direaksikan dengan 3-4 tetes larutan $\mathrm{FeCl}_{3}$. Jika terjadi perubahan warna menjadi biru kehitaman mengindikasikan adanya fenol. ${ }^{8}$

- Flavonoid

Ekstrak direaksikan dengan beberapa tetes larutan $\mathrm{NaOH}$, jika terdapat perubahan warna dari kuning pekat menjadi bening saat ditambahkan larutan asam mengindikasikan adanya flavonoid. ${ }^{8}$

- Terpenoid

Ekstrak ditimbang 0,5 gram ditambahkan $2 \mathrm{ml}$ kloroform, $\mathrm{H}_{2} \mathrm{SO}_{4} 3 \mathrm{ml}$. Jika muncul warna cokelat kemerahan maka menunjukkan adanya terpenoid. ${ }^{8}$

- Alkaloid

Ekstrak sebanyak $3 \mathrm{ml}$ diletakkan dalam cawan porselin, ditambahkan $5 \mathrm{ml} \mathrm{HCl} 2 \mathrm{M}$, diaduk dan kemudian didinginkan pada temperatur ruangan. Setelah sampel dingin ditambahkan $0,5 \mathrm{~g} \mathrm{NaCl}$ lalu diaduk dan disaring. Filtrat yang diperoleh ditambahkan $\mathrm{HCl} 2 \mathrm{M}$ sebanyak 3 tetes, kemudian dipisahkan menjadi 3 bagian $\mathrm{A}, \mathrm{B}$ dan $\mathrm{C}$. Filtrat A sebagai blangko, filtrat B ditambah pereaksi Mayer, filtrat C ditambah pereaksi Wagner. Apabila terbentuk endapan pada penambahan pereaksi Mayer dan Wagner maka identifikasi menunjukkan adanya alkaloid. ${ }^{6}$

\section{Evaluasi Etosom ${ }^{7,8}$ \\ - Uji Organoleptik}

Uji organoleptik dilakukan dengan cara melihat bentuk, warna, dan bau.

- Uji Nilai pH

Uji nilai $\mathrm{pH}$ etosom dilakukan menggunakan $\mathrm{pH}$ meter. $\mathrm{pH}$ meter dikalibrasi, kemudian dibersihkan dengan akuades. Indikator $\mathrm{pH}$ meter dimasukkan dalam etosom hingga didapatkan nilai yang stabil.

- Pengukuran vesikel

Diameter etosom diukur menggunakan Particle Size Analyser (PSA).

- Uji Morfologi

Permukaan etosom diuji dengan TEM (Transmission Electron Microscopy) yang ditempatkan pada tembaga berlapis karbon, setelah 15 menit diwarnai dengan $1 \%$ larutan asam fosfotungstat.

Interpretasi Hasil

- Uji Stabilitas Real Time

Menggunakan metode uji stabilitas real time yang dimodifikasi dengan suhu $25,0^{\circ} \mathrm{C} \pm 2,0^{\circ} \mathrm{C}$ dan relative humidity $60,0 \% \pm 5,0 \%$. Dilakukan pemeriksaan organoleptik, morfologi vesikel, uji $\mathrm{pH}$ dengan $\mathrm{pH}$ meter, dan uji aktivitas antioksidan menggunakan metode DPPH. Evaluasi dilakukan selama 30 hari (hari ke-0, ke-15, dan ke30).

\section{- Uji Aktivitas Antioksidan}

Perbandingan antara vitamin C $10 \mathrm{mg}$ dalam $20 \mathrm{ml}$ dan ekstrak daun jeruk purut $10 \mathrm{mg}$ dalam $20 \mathrm{ml}$. Keduanya ditotolkan sebanyak $1 \mathrm{ml}$, kemudian disemprot dengan larutan DPPH 100 ppm yang berwarna ungu pekat pada setiap totolan hingga plat KLT berlatar ungu.

- Uji Nilai Antioksidan (Uji Kuantitatif)

Metode pengujian aktivitas antioksidan yang digunakan adalah $\alpha$-diphenyl- $\beta$-picrylhydrazyl (DPPH) 
Sigma Aldrich secara in-vitro menggunakan spektrofotometri $U V$-Vis, metode yang digunakan dengan prosedur kerja sebagai berikut:

1. Sebanyak $1 \mathrm{ml}$ ekstrak tanaman diambil dalam tabung uji.

2. Disiapkan $2 \mathrm{ml}$ larutan DPPH 0,004\%.

3. Larutan (1) dicampurkan dengan larutan (2) hingga volume akhir $3 \mathrm{ml}$.

4. Divortex selama 10 menit dalam $22^{\circ} \mathrm{C}$.

5. Dibiarkan kondisi gelap selama 60 menit (pada menit ke 1, 30, dan 60 dihitung absorbansinya)

6. Sampel kontrol disiapkan dengan volume yang sama tanpa campuran ekstrak. Etanol disiapkan sebagai standar.

7. Diukur absorbansinya dengan standar asam askorbat bermerk Sigma Aldrich pada $517 \mathrm{~nm}$ dengan menggunakan spektrofotometer $U V$-vis.

Nilai absorbansi yang didapatkan dicatat dan dimasukkan dalam rumus:

"\%Inhibisi = " ["Blanko - Sampel" /"Blanko"]" × 100

Keterangan :

Blanko : absorbansi kontrol (berisi campuran etanol dan DPPH)

Sampel : absorbansi senyawa uji

Hasil persen inhibisi $\left(\mathrm{IC}_{50}\right)$ didefinisikan sebagai konsentrasi ekstrak yang mampu menghambat 50\% dari total radikal DPPH. IC50 dari sampel dinyatakan dalam $\mathrm{mg} / \mathrm{ml}^{12}$

Aktivitas antioksidan dibagi berdasarkan nilai $\mathrm{IC}_{50}$, rentang masing-masing nilai $\mathrm{IC}_{50}$ memiliki interpretasi yang berbeda seperti pada Tabel 1 .

Tabel 1. Klasifikasi Nilai Antioksidan Berdasarkan $\mathrm{IC}_{50}{ }^{32}$

\begin{tabular}{cc}
\hline Nilai Antioksidan & Interpretasi \\
\hline $\mathrm{IC}_{50}<50 \mathrm{ppm}$ & Sangat Kuat \\
\hline $50-100 \mathrm{ppm}$ & Kuat \\
\hline $101-150 \mathrm{ppm}$ & Sedang \\
\hline $\mathrm{IC}_{50}>150 \mathrm{ppm}$ & Lemah \\
\hline
\end{tabular}

\section{Hasil}

\section{Ekstraksi}

Ekstrak daun jeruk purut dibuat dengan metode maserasi 165 gram serbuk daun jeruk purut (Citrus hystrix D. C.) yang berwarna hijau tua dalam larutan etanol $96 \%$. Rendemen ekstrak daun jeruk purut yang didapatkan sebesar 9,85\%. Ekstraksi dilakukan dengan pelarut etanol $96 \%$ dengan perbandingan 1:5, kemudian dilakukan pengeringan dengan rotary evaporator pada suhu $60^{\circ} \mathrm{C}$ dengan kecepatan 80 rpm. ${ }^{17}$ Berdasarkan hasil skrining fitokimia, positif mengandung senyawa fenol, terpenoid, alkaloid dan flavonoid. Hasil uji organoleptik pada formula 1, formula 2 dan formula 3 yaitu bentuk zat cair, warna hijau kekuningan dan berbau khas aromatis.

\section{Uji Ukuran Vesikel}

Berdasarkan hasil ukuran vesikel formula 1, formula 2 dan formula 3 memiliki ukuran vesikel masingmasing sebesar 17,086 $\pm 28,491 \mu \mathrm{m} ; 52,872 \pm 42,553 \mu \mathrm{m}$ dan $27,489 \pm 38,634 \mu \mathrm{m}$. Formula 1 memiliki ukuran vesikel yang paling kecil (Gambar 1)

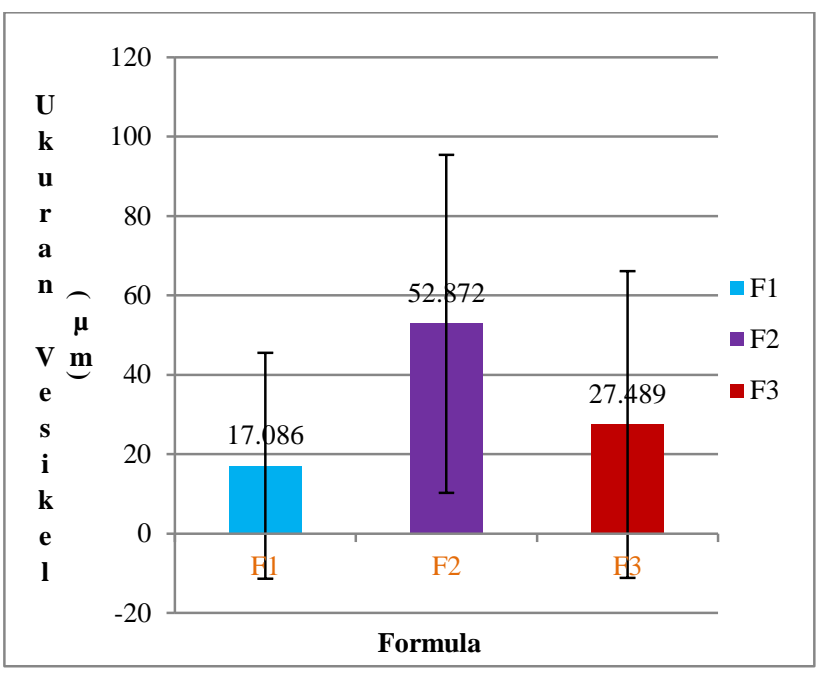

Gambar 1. Grafik Ukuran Vesikel Formula 1, Formula 2 dan Formula 3

Uji Stabilitas Ukuran Vesikel Etosom Daun Jeruk Purut

Hasil uji stabilitas ukuran vesikel selama penyimpanan suhu $25,0^{\circ} \mathrm{C} \pm 2,0^{\circ} \mathrm{C}$ dan relative humidity $60,0 \% \pm 5,0 \%$ ukuran vesikel formula 1 , formula 2 dan formula 3 memiliki rata-rata ukuran vesikel masing-masing sebesar 17,086 \pm 28,491 $\mu \mathrm{m} ; 52,872 \pm$ 42,553 $\mu \mathrm{m}$ dan $27,489 \pm 38,634 \mu \mathrm{m}$. Formula 1 memiliki ukuran vesikel paling kecil (Gambar 2).

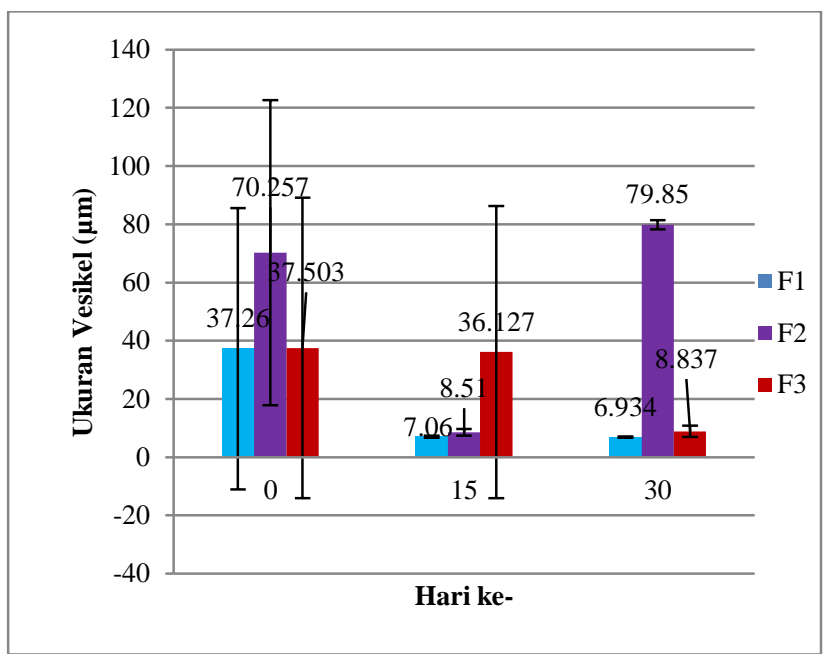

Gambar 2. Grafik Uji Stabilitas Ukuran Vesikel Etosom Daun Jeruk Purut pada Suhu Ruang.

\section{Uji Stabilitas pH Etosom Daun Jeruk Purut}

Hasil uji $\mathrm{pH}$ formula 1 , formula 2 dan formula 3 tidak mengalami perubahan secara signifikan dan sesuai dengan rentang $\mathrm{pH}$ kulit (4,5-6,6) (Gambar 3). 


\section{Uji Antioksidan}

Berdasarkan uji pendahuluan, totolan pada ekstrak daun jeruk purut berwarna kuning, sedangkan totolan pada vitamin C (blanko positif) berwarna putih, yang menunjukkan aktivitas antioksidan vitamin $\mathrm{C}$ dalam menetralkan radikal bebas DPPH yang berwarna ungu Gambar 4). Nilai antioksidan rata-rata $\mathrm{IC}_{50}$ pada vitamin $\mathrm{C}$ sebesar 4,793 $\pm 0,047 \mathrm{ppm}$, ekstrak daun jeruk purut sebesar $25,907 \pm 0,187 \mathrm{ppm}$, etosom ekstrak daun jeruk purut formula 1, formula 2 dan formula 3 masing-masing sebesar $28,814 \pm 0,431$ ppm; 32,299 $\pm 1,893$ ppm; $30,234 \pm 0,531$ ppm. Nilai $\mathrm{IC}_{50}$ untuk sampel, paling tinggi dimiliki formula 1, karena memiliki rata-rata $\mathrm{IC}_{50}$ paling kecil dibanding formula 2 dan formula 3 (Gambar 5).

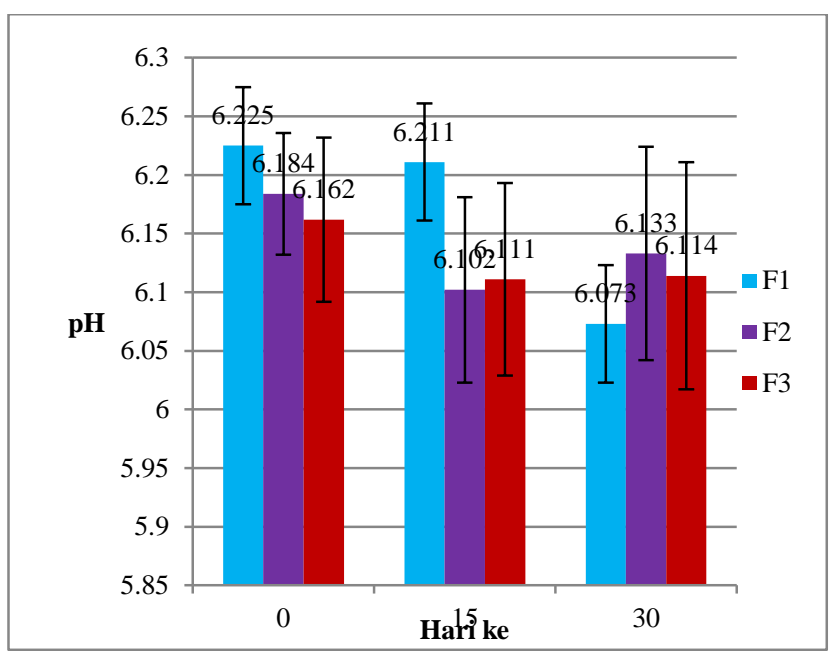

Gambar 3. Grafik Uji Stabilitas pH Formula 1, Formula 2 dan Formula 3 Etosom Ekstrak Daun Jeruk Purut pada Suhu Ruang.

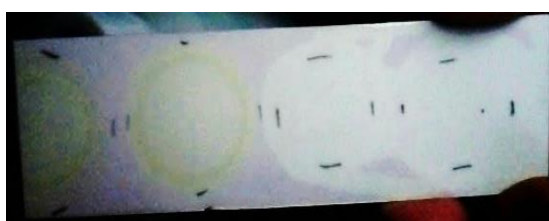

(A)

(B)

(C)

(D)

Gambar 4. Gambar Uji Pendahuluan Antioksidan Ekstrak Daun Jeruk Purut (A dan B) dengan Blanko Vitamin C (C dan D).

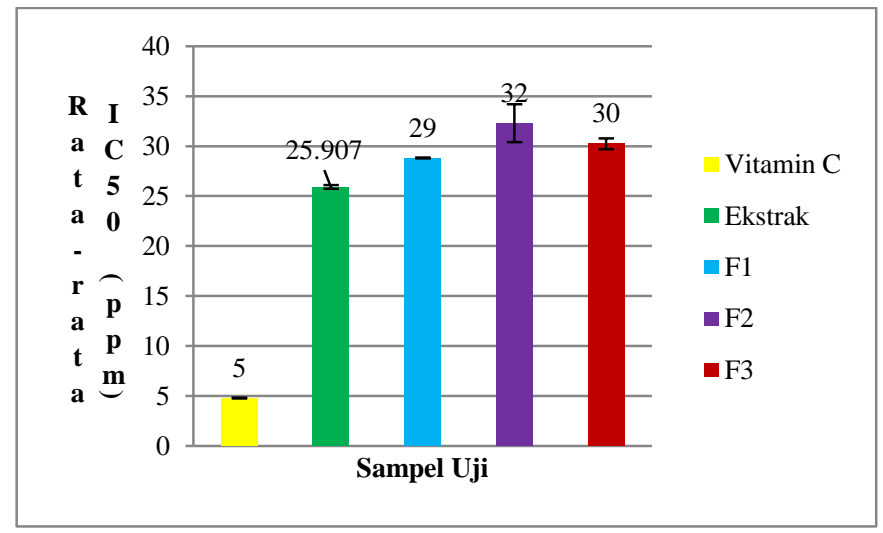

Gambar 5. Grafik Rata-rata $\mathrm{IC}_{50}$ antara Vitamin C, Ekstrak Daun Jeruk Purut, Formula 1, Formula 2 dan Formula 3

\section{Persen Penjerapan}

Hasil pengujian persen penjerapan dapat dilihat pada Gambar 6.

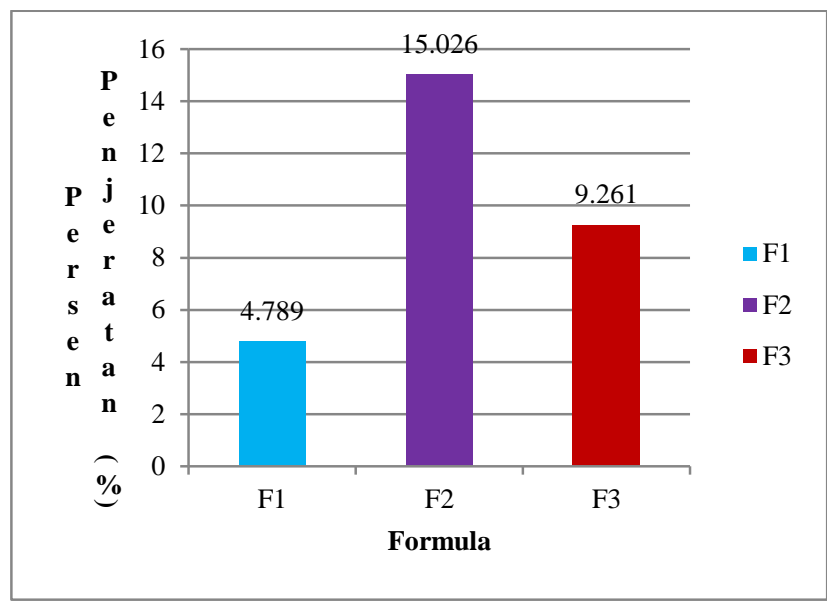

Gambar 6. Persen Penjerapan Formula 1, Formula 2 dan Formula 3.

\section{Diskusi}

Ekstrak daun jeruk purut (Citrus hystrix D.C.) berdasarkan hasil skrining fitokimia, positif mengandung senyawa fenol, terpenoid, alkaloid dan flavonoid. Pada senyawa fenol, peran utama aktivitas antioksidan terdapat pada struktur rantai samping cincin aromatisnya. Aktivitas peredaman radikal bebas senyawa fenol dipengaruhi jumlah dan posisi atom hidrogen $\left(\mathrm{H}^{+}\right)$. Senyawa fenol berpotensi sebagai antioksidan dengan menyumbangkan atom hidrogen, maka dapat menghasilkan reaksi netralisasi radikal bebas atau menghentikan reaksi radikal berantai yang terjadi. ${ }^{18}$

Potensi antioksidan yang dimiliki flavonoid berasal dari kemampuan mendonorkan elektron ke senyawa radikal bebas. Mekanisme tersebut membuat flavonoid memiliki efek menekan kerusakan jaringan oleh radikal bebas. ${ }^{19}$ Senyawa alkaloid, terutama indol, memiliki kemampuan untuk menghentikan reaksi rantai radikal bebas secara efisien dengan mendonorkan elektron ke senyawa radikal bebas. ${ }^{20}$ Terpenoid memiliki ikatan rangkap terkonjugasi sehingga dapat mentransfer hidrogen. ${ }^{21}$

Menurut Poland, et al., 2013, ukuran vesikel dengan ukuran mikro tidak dapat menembus dermis. ${ }^{22}$ Menurut Badenhorst, 2014, jika ukuran vesikel $>10 \mu \mathrm{m}$ penetrasi sampai ke permukaan kulit, 3-10 $\mu \mathrm{m}$ akan berkonsentrasi dalam folikel rambut dan ukuran vesikel $<3$ $\mu \mathrm{m}$ akan dapat menembus stratum korneum. ${ }^{23}$ Berdasarkan hasil yang didapat hasil PSA, rata-rata ukuran vesikel masing-masing formula 1 , formula 2 , dan formula 3 sebesar $17,086 \pm 28,491 \mu \mathrm{m} ; 52,872 \pm 42,553 \mu \mathrm{m}$ dan $27,489 \pm$ $38,634 \mu \mathrm{m}$. Hasil yang didapat, rata-rata ukuran vesikel akan penetrasi sampai stratum korneum dan ukuran vesikel tidak sesuai dengan spesifikasi yang diharapkan yaitu 50$200 \mathrm{~nm}$. Ada beberapa faktor yang menyebabkan perbedaan ukuran vesikel, yaitu komposisi bahan, sonikasi dan 
kecepatan pengadukan.

Komposisi etosom yang memberikan pengaruh pada ukuran vesikel adalah fosfatidilkolin dan etanol. Menurut Dave, 2010, jika konsentrasi fosfatidilkolin terlalu rendah maka vesikel yang terbentuk hanya sedikit dan jika konsentrasi fosfatidilkolin terlalu tinggi maka vesikel terlalu lunak dan menyebabkan kebocoran pada vesikel sehingga menurunkan nilai efisiensi penjeratan. ${ }^{24}$

Sonikasi yang dilakukan pada penelitian ini selama 45 menit dalam satu siklus, perlakuan ini lebih lama dibanding pustaka. Sonikasi dilakukan untuk memperkecil ukuran vesikel dengan memanfaatkan energi ultrasonik. Sonikasi bekerja dengan mengubah sinyal listrik menjadi getaran secara mekanis. Pada penelitian Yamaguchi et al., 2009, menyebutkan bahwa frekuensi dan lama waktu sonikasi mempengaruhi ukuran vesikel. ${ }^{25}$ Jika sampel terlalu lama mendapatkan getaran mekanis, dapat menyebabkan aglomerasi pada vesikel. Lama waktu sonikasi yang dilakukan pada penelitian ini selama 45 menit, sementara menurut Chandarn, 2012, sonikasi dilakukan selama 5 menit dengan 3 kali siklus dan setiap pergantian siklus diberi jeda 5 menit. ${ }^{26}$ Menurut Yamaguchi, 2009, dengan paparan ultrasonik yang singkat lebih baik dibanding paparan ultrasonik yang lama. ${ }^{25}$ Menurut Gad, 2008, posisi sampel saat sonikasi mempengaruhi ukuran vesikel agar ultrasonik dapat terkonsentrasi pada sampel. ${ }^{27}$

Kecepatan pengadukan mempengaruhi ukuran vesikel yang diinginkan, pengadukan tidak boleh terlalu cepat dan tidak terlalu lambat. Jika terlalu cepat, maka terjadi benturan antar vesikel sehingga menyebabkan ukuran yang lebih besar, pengadukan yang cepat juga menghasilkan busa yang terlalu banyak karena banyaknya udara yang terperangkap. Sedangkan jika pengadukan lambat, maka bahan-bahan akan sulit homogen. Menurut Babaie et, al., 2015, kecepatan pengadukan etosom dapat divariasi dimulai $700-22.000 \mathrm{rpm}^{28}$

Efisiensi penjeratan bahan aktif ekstrak daun jeruk purut dalam vesikel etosom di pengaruhi oleh komposisi fosfatidilkolin dan etanol. Fosfatidilkolin berperan penting dalam pembentukan vesikel yang akan menjerat obat. Semakin besar kandungan fosfatidilkolin maka penjerapan obat akan semakin besar karena peran dari fosfatidilkolin sebagai penjerap bahan aktif . ${ }^{29}$

Pada penelitian yang dilakukan, nilai efisiensi penjeratan pada formula 3 memiliki persentase penjerapan lebih kecil dibanding formula 2 karena adanya pengaruh pembuatan etosom pada tahap sonikasi. Menurut Sugiyati, 2015, suhu mempengaruhi ukuran vesikel..$^{30}$ Pengaruh suhu terhadap vesikel menunjukkan bahwa lesitin soya memiliki titik suhu transisi. Pada suhu yang lebih tinggi, dapat terjadi kerusakan susunan membran lipid. ${ }^{31}$ Pada penelitian yang dilakukan, suhu saat sonikasi menggunakan suhu terendah pada alat sebesar $40^{\circ} \mathrm{C}$, sementara suhu yang diperlukan untuk memekatkan fase lipid dalam air memerlukan suhu ruangan agar terbentuk fase gel. Suhu pada saat dilakukan sonikasi, diantisipasi dengan memberi es pada wadah sonikator, namun suhu tidak dimonitoring sehingga apabila suhu es sudah mulai naik, pembentukan vesikel selama proses sonikasi akan terganggu.

Nilai $\mathrm{IC}_{50}$ vitamin C sebesar 4,793 $\pm 0,047$. Nilai $\mathrm{IC}_{50}$ ekstrak daun jeruk purut sebesar 25,907 $\pm 0,187 \mathrm{ppm}$. Nilai IC $_{50}$ sampel etosom ekstrak daun jeruk purut formula 1 sebesar 28,814 $\pm 0,431 \mathrm{ppm}$, formula 2 sebesar 32,299 \pm $1,893 \mathrm{ppm}$ dan formula 3 sebesar $30,234 \pm 0,531 \mathrm{ppm}$. Vitamin C, ekstrak dan sampel memiliki potensi aktivitas antioksidan sangat kuat seperti pada Tabel 1.

\section{Daftar Pustaka}

1. Gragnani Alfredo, Sarita Mac Cornick, Verônica Chominski, Samuel Marcos Ribeiro de Noronha, Silvana Aparecida Alves Corrêa de Noronha dan Lydia Masako Ferreira. Review of Major Theories of Skin Aging 3. 2014. Department of Surgery, Federal University of Sao Paulo, Paulista School of Medicine (UNIFESP-EPM) 265-284.

2. Rakesh R.Ethosomes for Transdermal and Topical Drug Delivery. 2012. Department of Pharmaceutics, Amrita School of Pharmacy, AIMS Health Sciences Campus, India. Vol 4, Suppl 3.

3. Umi K. L., 2015. Pengaruh Perlakuan Pendahuluan terhadap Karakteristik Mutu Minyak Atsiri Daun Jeruk Purut (Citrus hystric D.C.) Jurusan Teknologi Hasil Pertanian. Universitas Sebelas Maret: Surakarta.

4. Saleh M., Clark Shavon., Brooke W., dan Suziat A., 2010. Antioxidant and Free Radical Scavenging Activities of Essential Oils. Volume 20.

5. Kedare S.B., 2011. Genesis and development of DPPH method of antioxidant assay. 48(4):412-422

6. Pratima Anna Nikalje, Shailee Tiwari. Ethosomes: A Novel Tool for Transdermal Drug Delivery IJRPS. 2012 2(1), 1-20.

7. Barupal A. K., Gupta Vandana dan Suman Ramteke. Preparation and Characterization of Ethosomes for Topical delivery of Aceclofenac. 2010. Indian J Pharm Sci. Sep-Oct; 72(5): 582-586.

8. Wagner HXS, Bladt Z dan Gain EM. Plant drug analysis. Springer Veralag.1996. 360 Berlin, Germany.

9. Dewi Marliana Soerya, Suryanti Venty dan Suyono. Skrining Fitokimia dan Analisis Kromatografi Lapis Tipis Komponen Kimia Buah Labu Siam (Sechium edule Jacq. Swartz.) dalam Ekstrak Etanol. 2005.(1): 26-31. ISSN: 1693-2242.

10. Shi, Tran K, dan Lio. A comparison of physicochemical properties of a selection of modern moisturizers: hydrophilic index and pH. 2012. J. Drugs Dermatol May;11(5):633-6.

11. Bhalaria K. M, Sachin Naik dan Misra A. N. Ethosome: A Novel Delivery System for Antifungal Drugs in the Treatment of Topical Fungal Disease.2009. Volume 47, Mei368-375.

12. Jamilah, Abdulkadir Gedi, M., Suhaila, M.dan Md. 
Zaidul. Phenolics in Citrus hystrix leaves obtained using supercritical carbon dioxide extraction. 2011.International Food Research Journal 18(3): 941 948.

13. Sen. Treatment of Microarray Experiments as Splitplot Designs. 2003. Journal of Bipharmaceutical Statistics, 13, 159-178.

14. Plichta, S., dan Garzon, L. Statistics for nursing and allied health. 2009. New York, NY: Lippincott Williams \& Wilkins.

15. Riyanto dan Bambang. Dasar-dasar Pembelajaran Perusahaan. 2010. Yogyakarta: BPFE.

16. Feng Xiaolong, Lantong Zhang dan Huiming Zhu. Comparative Anticancer and Antioxidant Activities of Different Ingredients of Ginkgo biloba Extract (EGb 761). 2009. 75: 792-796.

17. Depkes RI. Parameter Standar Umum Ekstrak Tumbuhan Obat Cetakan Pertama. 2000, Jakarta : Depkes RI. Hal. 10-11.

18. Ghidouche S., Es-Safi dan Ducrot. 2007. Molecule 122228.

19. Shahidi F, Kadaswarmi, Middleton, dan Shukla. Natural Antioxidants: Chemistry, Health Effects, and Applications. 1997. AOCS Press, Illionis.

20. Chung H. S dan Woo W. S. 2001. Journal Natural Product 64-12 1579.

21. Capelli, B. and Cysewski, G. Natural Astaxanthin: King of the Carotenoids. 2007. Holualoa: Cyanotech Corporation, pp. 11-22.

22. Poland, C.A., Read, S.A.K., Varet, J., Carse, G., Christensen, F.M., dan Hankin, S.M. Dermal Absorption of Nanomaterials. 2013. The Danish Environmental No. 1504 Protection Agency Strandgade Copenhagen, Denmark

23. Badenhorst Travis, Svirskis1 Darren dan Wu Zimei. Pharmaceutical Strategies for the Topical Dermal Delivery of Peptides/Proteins for Cosmetic and Therapeutic Applications. 2014. Austin J Pharmacol Ther - Volume 2 Issue 6.

24. Dave Vivek., Dhirendra Kumar, Shaila Lewis dan Sarvesh Paliwal. Ethosome for Enhanced Transdermal Drug Delivery of Aceclofenac. 2010. In-ternational Journal of Drug Delivery 2, No.81-92.

25. Yamaguchi, Akita H, Kudo A, Minoura A, Khalil A, Moriguchi R, dkk. Multi-layered nanoparticles for penetrating the endosome and nuclear membrane via a step wise membrane fussion process. 2009. Biomaterials 30:2940-2949.

26. Chandarn Sarat, Shirwaikar Arun, Sarala Devi dan Vipin K. Comparative Evaluation of Sonicated and Un-Sonicated Ethosomes Containing Ketoconazole. 2012. International Journal of Advances In Pharmacy, Biology And Chemistry - Vol. 1(1), Jan- Mar.

27. Gad Shayne Cox. Production and processes. 2008 Pharmaceutical manufacturing Handbook. Wiley John \& Son Inc, Canada, 259.

28. Babaie et, al. Nanoethosomes for Dermal Delivery of
Lidocaine.2015. Adv Pharm Bull 5(4), 549-556.

29. Venkateswarlu, Jayashankar, Ramesh, Viswanatha, Pravallika dan Suneetha. A Review on Liposomes. 2011. RJPBCS. 2(3).739-751.

30. Sugiyati Rini, Iskandarsyah, Joshita Djajadisastra. Formulasi dan Uji Penetrasi In Vitro Sediaan Gel Transfersom Mengandung Kofein sebagai Antiselulit. 2015. Jurnal Ilmu Kefarmasian Indonesia, September, Hlm. 131-136.

31. Liu K. S. Y., Siebert M., Mertel S., Knoche E., Wegener S., dan Wichmann C. RIM-binding protein, a central part of the active zone, is essential for neurotransmitter release. 2011. Science 334, 15651569. 10.1126.

32. Ariyanto R., 2006. Uji Aktivitas antioksidan, Penentuan Kandungan Fenolik dan Flavonoid Total Fraksi Kloroform dan Fraksi Air Ekstrak Metanolik Pegagan (Centella asiatica L. Urban), Skripsi, Fakultas Farmasi Universitas Gadjah Mada. 